Article

\title{
Leveraging Digital Approaches for Transparency in Sustainable Supply Chains: A Conceptual Paper
}

\author{
Frank Ebinger and Bramwel Omondi * \\ Department of Sustainability-oriented Innovations and Transformation Management, \\ Nuremberg Campus of Technology (NCT), 90429 Nürnberg, Germany; frank.ebinger@th-nuernberg.de \\ * Correspondence: bramwel.omondi@th-nuernberg.de; Tel.: +49-(0)911-5880-3224
}

Received: 18 June 2020; Accepted: 27 July 2020; Published: 30 July 2020

\begin{abstract}
With the growing global interdependence of companies, their scope of responsibility for the environmental, social, and human rights impacts associated with their activities is also growing. In this context, companies are increasingly held accountable for social and ecological issues that lie within the sphere of action of their suppliers and sub-suppliers. They are thus faced with the challenge of meeting these demands for transparency, traceability, and compliance with standards in their Supply Chains (SCs). Based on the theoretical framework of Sustainable Supply Chain Transparency (SSCT) in Sustainable Supply Chain Management (SSCM), this conceptual article aims at initiating the discussion on digitalization in SSCM. Therefore, a heuristical research framework, based on relevant fields in the management of sustainability oriented transparency (governance, cooperation and partner selection, traceability/tracking, and strategic and operational risk assessment) is developed. In relation to these fields, consequently, data-driven digital approaches are identified to which potentials for SSCT and control can be attributed. This initial analysis of existing digital approaches already shows that the market is developing dynamically, but is driven more by individual initiatives. In many cases, the approaches used so far are still in the trial phase or offer only limited solutions. Therefore, this paper contributes by giving an overview of the current application of the digitalization approaches in SSCM pinning our discussion on SSCT dimensions.
\end{abstract}

Keywords: sustainable supply chain management; data-driven technologies; sustainable supply chain transparency; blockchain technology; artificial intelligence; cloud-computing

\section{Introduction}

Social and environmental sustainability has become an increased momentum in the debate on Global Supply Chains (GSCs). This is particularly illustrated with the fact that it is becoming progressively important for companies to pay attention to the way in which situations of human rights violations, child labour, inhuman working conditions, corruption and bribery, or non-compliance with environmental standards (e.g., breaches of legal limits) are taken into account in various economic sectors or regions of the world. The identification and dealing with such social and environmental issues in GSCs are a significant dimension of corporate social responsibility (CSR) [1].

However, the situation has further been complicated by the structural and dynamic complexity nature of GSCs [2] resulting from trends such as outsourcing (also known as international or global sourcing) [3] and diverse and dispersed consumers-base [4-6]. These developments are particularly driven by globalization, consumerism, and advancements in information and communication technology era [3]. For instance, GSCs operate across multiple regulatory boundaries, exposing involved companies to pressures from consumers, civil society, and government agencies to take the full responsibilities for the actions of their suppliers and supplier's suppliers far away from their organizational boundaries [7]. Such complexity in GSC makes it difficult for the visualization and 
management of the entire SC. Especially with the fact that some of the sub-suppliers/sub-contractors are located in emerging markets where the responsibilities and control mechanisms of companies are limited or restricted [8]. As a result, these areas are prone to sustainability-related risks and uncertainties $[9,10]$, whose conceptualization in supply chain management (SCM) literature remains vague [11].

As such, calls for transparency along the GSCs has gained momentum as an instrument to facilitate controlling and monitoring of activities of the entire GSC and manage SC-related risks [12]. The topic of Supply Chain Transparency (SCT) has been widely examined in scholarly work [4,10,13-23] with an indication that companies focus more and more on CSR and sustainability matters, as well. However, this assessment might not extend in the long run due to various challenges [17,24]. With such an extensive exploration and exploitation of SCT [14], the structural and institutional impacts remain still open. Nonetheless, one shared understanding among scholars in this field is that this concept is associated with the disclosure and sharing of information as a tool for better governance of SCs [25].

However, attaining such a disclosure in a multi-stakeholder network is easier in theory than in practice due to organizational and structural challenges [18]. First and foremost, despite efforts by various sectors and countries which have introduced regulations and standards to support SSCT across industries such as Agribusiness [18], this concept is still mainly a voluntary affair [26]. Secondly, the massive data from the multi-stakeholders involved in GSCs can result in a high potential of information overloads to the users [27], which might lead to decision obstruction [28]. Similarly, some companies deem information about suppliers and sub-suppliers as a competitive advantage [4]; thus, they might act as gatekeepers to access such information and data [29]. In this regard, understanding stakeholders' information needs pose a challenging task to the SSCT. For instance, conflicting interests among the actors in SCM and information asymmetries have been noted as significant concerns in information disclosure [30]. Similarly, most categorized information has focused more on economic information [31] and ignored environmental and social sustainability information. For example, Lotfi et al. [32] categorize SCs information into inventory, sales, forecasting, order, product ability, and other information. Thus, the need for conceptual and analytical tools for deriving valuable information from this massive data for sustainable SSCT grows [29].

Consequently, the attention in digital approaches as instruments to enhance transparency in GSCs raises. For instance, the use of big data and Blockchain technologies are used for GSCs' activities monitoring and assessment [33]. Nevertheless, the field of transparency in SSCs in connection with digital technologies is still a very young one [34]. Even though the development is dynamic in practical application, it is driven by individual initiatives (especially small and medium enterprises compared to large multinational corporations) and approaches. Additionally, these initiatives are still in the trial phase, or offer only a limited range of solutions. Comprehensive implementation and operational strategies of the digital tools are often missing. Furthermore, there is a lack of theoretical foundation of research on digital approaches to SSCM.

SSCT has been termed as the basic 'requirement in SSCM, and with it, the seeds for ethical- and quality-related product and process innovations, as well as supplier development can be sowed' [14, p. 564]. With this in mind, the aim of this conceptual paper is to discuss, based on existing approaches in SSCM in combination with SSCT, relevant fields in the management of sustainability oriented transparency (Section 2). Based on the identified fields, an heuristic framework is developed, which is used to identify and classify existing digital solutions, discussing the potential, the contribution, and the shortcomings of different digital solutions for SSCT (Section 3). In summary, we aim at providing an integrated framework of SSCT and digitalization as a potential solution, and highlight directions for future research (Section 4).

To the best of the authors' knowledge, substantial research exists in the area of questions about data security or the protection of intellectual property or company secrets. It is important to note from the outset that our study is, at this point of conceptional stage, not concerned with the risks and limits of these digital approaches. 


\section{Dimension and Challenges of SSCT}

\subsection{Overview of SSCM}

Currently, companies are expected to undertake sustainability activities as part of their business model and not only focus on profits gaining and satisfying their shareholders, but also function as global corporate citizens [35]. This has drawn the attention of both practitioners and scholars to the field of CSR and SSCM. For instance, Ağan et al. [36] conclude that there is a positive correlation between CSR and the environmental suppliers' development which, in turn, enhance the firm's performance [36]. Likewise, Li et al. [37] support that, in order to improve their brands and reduce reputational risks, companies have placed CSR and sustainability [38] as part of their contribution to the sustainable development goals (SDGs) [35]. On their side, Awaysheh and Klassen [39] and later, Yawar and Seuring [1] highlight the social sustainability in SCM as a responsibility of companies.

The last two decades have seen a growing number of scholarships in the area of SSCM [40]. For instance, [41-45], just to mention a few. However, the present article is focused on presenting SSCM in its broadest sense, incorporating SCM researches that address social and ecological elements of performance and treating them as equally valid as economic performance claims. As such, the study adopts the Pagell and Shevchenko' [46] definition as "SSCM is the designing, organizing, coordinating, and controlling of SCs to become truly sustainable with the minimum expectation of a truly sustainable SC being to maintain economic viability while doing no harm to social or environmental systems." (p.44) Therefore, SSCM indicates the interaction between the SC stakeholders to ensure that there are no violations of social and environmental conditions (e.g., child labour, environmental challenges, and corruption) across SC while still maintaining profitability [47]. With companies focusing on achieving SSCM, competition for competitive advantage is shifting from the traditional intercompany competition to intra-supply chain competition [17,48,49]. This, according to Gold et al. [50], has led to the emerging of a 'collaborative paradigm' in SCM. Where cooperation among SC stakeholders becomes a significant source of competitive advantage; likewise, such collaboration becomes critical when SCs focus on ensuring the sustainability performance of their products and services [50].

Based on this understanding, trust among the stakeholders plays a vital role in the success of SSCM and collaboration [51]. Companies focus on understanding the entire network based on mutual benefits, which aim at less power play and more exchange of value [52]. This new relationship paradigm also lowers transaction costs (reduction of costs to inspect, verify and certify SC partners) [51] and SC-related risks in the effort to deliver value [35,52]. Consequently, Literature on SSCM and Trust have indicated that information disclosure and sharing is central to the success of SCs as it enhances accountability [43]. For instance, the disclosure of information by the SC stakeholders increases the trust and commitment levels by reducing the behavioural and reputational risks [51]. Similarly, functional and operational conflicts in SCs can be reduced by greater information sharing as indicated by [52]. However, in some regards, partners consider transparency not always as a positive approach. The dark side of transparency could be rooted in misuse of trust or the intentional covering of certain processes and risks (c.f. Section 2.2.3).

Even though the SSCM scholarships emphasize the importance of collaboration and information sharing, the commonality to all of the above is understanding SCs stakeholders' needs and expectations. This can be realized by an organized and transparent exchange of information among the supply chain actors. For instance, the exploitation, access, and effective use of information have the potential not only for the development of sustainable production and consumption, but also provide the corporations competitive advantages through value addition in the products and services that go beyond functionality, prices, and quality [53]. Understanding such stakeholder's information needs facilitates knowledge-based decisions, which are critical in promoting SSCM [37]. Hence, the calls for information transparency along value chains. As such, the next part analyses the concept of SSCT and dimensions of information as discussed by various scholars in the field. 


\subsection{Transparency in Sustainable Supply Chains}

\subsubsection{The Concept of Transparency}

Transparency in SC is seen as a positive aspect not only in the field of SCM, but also in society at large. As such, it is perceived as vital in the efforts to achieve more emancipatory environmental and social policies and actions [24]. Similarly, it is considered as a basis of good governance [25], incorporating the elements of openness and communication to enable stakeholders to understand steps that have already been taken, and those that are yet to be taken, in production and delivery processes [17]. Hence, to understand the importance of transparency in SCs, the following questions must be addressed. What types of transparency are needed and by which stakeholders? Is the transparency requirement focusing on the internal in the direction of the transaction partner or the external in the direction of society?

The examination of SSCT continues attracting attention among scholars in the SCM and Sustainability fields. This trend is linked to the increase in the stakeholders' expectation of sustainable production and consumption [54], with Egels-Zandén et al. [4] pointing out three fields in the debate of SSCT, namely, traceability, sustainability conditions, and purchasing practices. They further propose that, in order to achieve the objectives of SSCT, companies should adopt either a compliance or cooperation approach. In a compliance approach, they argue that SSCT is an end in itself and involves companies developing standard transparency policies that must be followed by suppliers and sub-suppliers. Non-complying stakeholders risk being locked out of the SC. With these shared policies, however, companies tend to have an oppressive relationship with the suppliers and sub-suppliers. This could jeopardize their relationships with other actors in the SC [4].

In contrast, cooperation approach seeks to minimize the power conflicts in SCs through normative rather than authoritative control. Transparency here is viewed as a collaboration among stakeholders and not as a stand-alone role for producers and suppliers alone [44]. In this approach, transparency is viewed as a means to an end and is associated with increased sustainability [55].

No matter the approach selected by the SCs actors, information disclosure and sharing plays a significant role in SSCT [56], and understanding different information dimensions will facilitate stakeholder's engagement and thus attaining the objective of SSCT. In doing so, companies can also analyze the importance of different positions or roles in the value network with regard to social or environmental factors. They can also determine which actors have a crucial function [57]—for example, assessing both local and expert stakeholders in terms of power and knowledge for decision-making purposes [56].

\subsubsection{Transparency Information Dimensions}

Based on the above analysis, transparency can be pointed out as an element of information exchange among parties, defined as information a company communicates to its stakeholders concerning the sustainability of its products, materials, services, and SC systems [58]. The volume of information, however, increases as the distance between product production and consumption increases [59], making it a difficult task to particularly derive useful information without understanding dimensions needed for transparency. Consequently, scholars have attempted to categorize the information in various dimensions concerning SSCT.

For instance, Hofstede clusters the information consisting of the past (History Transparency), the present (Operational Transparency), or the future (Strategy Transparency) [60]. History transparency refers to the traceability of past processes, including tracking and tracing. Operational transparency focuses on information concerning control of current operations such as collaborative logistics planning, while strategy transparency refers to the planning of future innovative processes (joint innovation) [60]. Likewise, Garcia-Torres et al. [19], propose traceability for sustainability (TfS) as a cyclical and evolving approach towards SSCT in achieving SSCM. They focus on governance, tracking and tracing, 
and collaboration as the key dimensions considering stakeholders expectations and in order to achieve performance growth, improved risk management, and transforming SC processes [19].

Firstly, at the governance level, TfS approach separates formal and informal information. Formal information, on the one hand, deals with the implementation of guidelines, regulations, codes of conduct, standards, and certifications that should be followed by all actors along the value chain [19]. For example, the 'Germany Supply Chain law', which is currently under discussion, and 'French Duty of Vigilance law' respectively provide a legally binding obligation for companies to identify and prevent environmental and human rights violations resulting from their entire SCs [61]. This type of information is mostly used in compliance transparency and is rooted in trust or mistrust among the actors of SC [19]. Due diligence processes, materiality analysis [62], and controlling the sustainability requirements are some of the governance mechanisms to enforce compliance in SCs.

Secondly, tracking and tracing level deals with upstream information distribution from customer to producer and downstream distribution from producers to the customer, respectively [60]. It placed as the ability to identify, verify, and monitor components, and the chronology of events taking place along the SC. According to Francisco and Swanson, this level focuses on the controlling of operations, processes, and products in a SC from raw material to the final product [54]. This information level, in particular, poses major challenges for companies, as the processes in SCs are influenced by their complexity, volatility, the lack of globally accepted standards, and the lack of skills or blockage of individual actors. On the other hand, traceability is a function that is now particularly demanded by consumers and consumer organizations, e.g., through proof of product chain certification.

Lastly, in the collaboration level, Garcia-Torres et al. argue that this emphasizes cooperation and development of long-term relationships among the stakeholders, thus successful management of SCs [19]. Such relationship facilitates the achievement of milestones that cannot be achieved with individual corporations. An essential basis for transparent and trustworthy cooperation is the development of a common understanding aimed at developing a common language, importance, and standards, such as the conventional interpretation of critical concepts, shared standards for product/service quality, mutual presentation of reference information, and common technological infrastructure [60].

What Garcia-Torres' approach to SSCM lacks, however, is the strategic and operational risk assessment perspective, which provides an expanded contextual perspective in which the whole supply chain operates. Information on specific industry and regional location risks (e.g., weather and climate risks) is included here, which is particularly important for SCs that operate with more regular operational violations, e.g., in connection with certain raw materials or production locations, in sectors that are vulnerable to human rights issues, or have to do with weather-related calamities. Here, for example, the exchange of information on sectoral level helps to identify places of reference and the associated social and ecological risks. In such a perspective, the boundaries of the actual SC are dissolved and the focus is extended to entire regions or sectors.

\subsubsection{Challenges to Transparency in SCs}

However, attaining the required SSCT has been easier in theory than in practice. Organizations seeking to enforce transparency in various SCs across the industries face several challenges, which range from organizational to structural challenges [18]. The complexity and dynamic structures and processes of SCs pose significant challenges for companies. These structures and SC processes have multiple interconnected dimensions (i.e., economic efficiency, sustainability, and risks and compliance management) [63]. In most cases, risks and problems are hidden in the depth of the value chain. Errors and shortcomings happen every day at all levels in complex SCs where the monitoring and the degree of influence of the buying companies are restricted. According to Sauer and Seuring [8], the restrictions occur at lower tiers, which are mostly located in the emerging markets. Likewise, for many companies and suppliers, it is difficult to assess the dimension of these shortcomings and 
to decide whether this information should be disclosed. Transparency creates responsibility for the errors, and a certain degree of lack of transparency is sometimes considered desirable.

Similarly, cultural differences among the actors also play a role here, which makes it difficult for companies to understand the requirements for achieving transparency [64]. For example, cultural differences can prevent suppliers from feeding data and information into databases because a culture of error-friendliness does not exist, and on the contrary, admitting errors or risks marks a social blemish. This leads to conflicts of interest between stakeholders and information asymmetries, which result in reduced quality of report content or less credible data in the disclosure of information [30].

Besides, data and information transparency always carry the risk of disclosing business secrets, copyright issues, or confidentiality issues [65]. Complete transparency about suppliers and their relationships is difficult to achieve, especially in complex SCs, due to fluctuation or lack of trust between partners. Information about business processes, suppliers, and subcontractors is still a decisive competitive advantage for many companies, and the exchange of such information can undermine the business model [4]. In addition to the risk of disclosing non-proprietary intellectual property, the disclosure of supplier data alone can, for example, lead to companies in the SC being able to bypass the reporting contractual partner and order directly [66]. Furthermore, the disclosure of data and information in areas of conflict is risky and not always desired, such as on 3TG conflict metals tantalum, tin, tungsten, and gold.

Finally, yet importantly, data and information are usually available in massive and dynamic quantities in all companies involved in the SCs [33]. However, organizing these data and information in a useful way and deciding which data should or must be passed on to the shared platform is a major challenge. The number of stakeholders to be addressed in complex SCs alone is large, and is further increased by constant fluctuation among suppliers and sub-suppliers. The sheer volume and velocity of change of data and the difficulties in allocating it in a structured manner lead to overload [27,67]. Such overload can ultimately lead to error accumulations or even decision blockades [28]. Therefore, the increasing calls for conceptual and analytical instruments to converting significant information from unorganized and unstructured data [68]. Thus, the need for digital approaches to SSCT. Features such as trend analysis, predictions, and optimization of activities make digital approaches suitable for not only for the performance of SCs, but also for SSCT [68].

\section{Digital Approaches and SSCT}

\subsection{Digital Approaches in SSCM}

The growing technology facing the world has resulted in a new wave of automation in various sectors of society [69]. This wave ranges from the use of robotics by companies and farms in areas such as production, manufacturing, planting and harvesting, and also in transportation [70], to the application of both Artificial Intelligence (AI) and Big Data Analytics (BDA) to facilitate the collection and construction of valuable information and competitive advantage from the massive data at their disposal [71]. Furthermore, some of these technologies are being applied in both developed and developing markets to monitor and control environmental risks and human rights challenges, hence sustainable production and consumption [72]. This illustrates the vital transformation in modern SCM where technologies are applied in the entire SC, unlike previously, where they were limited to production and internal communication [73,74]. Consequently, the growing application of technology in SCs has resulted in several digital approaches that act as tools for solving the challenges faced by companies in SCM [75], especially in attaining SSCT.

For instance, traceability and tracking food ingredients across suppliers and the various countries are currently facilitated by Blockchain Technology (BT) [76]. Similarly, BDA is applied to enhance visibility and give the companies real-time information for vital decisions [39]. Artificial Intelligence (AI), on the other side, utilizes its abilities to recognize various patterns and phenomena in business ecosystems to support companies in the decision making process [77]. Despite such potentials, the application of 
digital approaches in SSCM practice is still a very young one. To the best of our knowledge, the small number of initiatives or corporations that have implemented these approaches and for those initiatives is still in the early or testing stages. Why so? What are the suitable new technologies?

As a starting point, this paper acknowledges the availability of and the role played by Big Data (BD) facilitating transparency in SCM. As such, it focuses on digital approaches, which are characterized by the ability to collect and process volumes of data [78] and facilitate informed decision-making processes and risk management. It is also noted that in adopting these data-driven digital approaches, companies are influenced by the complexity of their SCs and business operations, innovative cultures, and the existence of a massive unstructured data [79]. The various characteristics and features of these approaches also facilitate their application in various SCs as individual approaches or a combination of two or more approaches.

BTs, for instance, has examined by various SCM researchers. For instance, Choi [80] analyses the application of BT supported platforms for the authentication and certification in the mineral industries. Likewise, Chod et al. examine how this approach facilitates securing of financial benefits through SSCT [81]. Characterized by decentralized, distributed, and tamper-proof digital transactions, BT enhances stakeholders trust in SC [82]. This way, it provides a platform for traceability, identification of counterfeits (through the allocation of unique identities to verify authentic goods), and for efficient transactions [83]. Salah et al. [84] indicate that with such traceability ability, the products' country of origin, compliance with sustainability certifications and standards, etc. can be assessed. BT based platforms are divided into two types, private and public. In the private platforms, the access is limited to the SCs stakeholders, and mostly developed and operated by the companies in a given SC, whereas in the public BT, information is accessible to every internet user [85]. BT platforms in SCs are mostly private, facilitating corporations among specified SC stakeholders.

Similarly, AI has emerged as a critical instrument for collecting, integrating, and processing data from various stakeholders and SC devices. Min [77] summarizes these objectives of AI as "the main objectives of AI are to understand the phenomenon of human intelligence and to design computer systems that can mimic human behavioural patterns and create knowledge relevant to problem-solving" (p. 14). In the textile industry for instance, companies process useful information from a massive unstructured but interconnected system. Therefore, the companies apply AI tools to enable the mastering of this information in order to optimize the decision-making processes [86]. Applying the ability to recognize business patterns and using these patterns to predict a potential future occurrence is useful in the cause and effect relationships, and on the one hand, is a critical element in SC risk management processes [77,87]. On the other hand, its abilities to incorporate multi-agent systems operations support the SC's ecosystems, which involves several stakeholders and entities with individualized agendas that sometimes overlap or conflict [87]. Despite such features and characteristics, the application of AI in SCM is still limited [77].

Cloud-computing and platform solutions, on the other hand, have been used in other industries such as banking, automobiles, and health care for long enough to incorporate the dispersed segments using fewer resources [15]. However, technology has created a digital platform that facilitates the optimization of both SC costs and operations [88]. This phenomenon has resulted in a new field of SC called Cloud SC, a term that was coined by [89] and defined as 'two or more parties linked by the provision of cloud services, related information and funds.' In this perspective, the cloud platform applies graphic networks developed by information generated by the different SC participants to provide software solutions and infrastructure for visualization of end-to-end SC networks [90]. With such networks, sustainability-related risks can be identified in real-time and action can be taken with the responsible parties [88]. Similarly, this technology supports collaboration among the SC partners, thus improving information sharing and visibility [15]. Additionally, the developing of cloud-computing has created new business models, i.e., Platform as a Service (PaaS) to technology giants such as Google, Amazon, and IBM [79], and cloud-based consumer relationship management applications for new entrants such as Sustainabill.de and Scoutbee GmbH. 
Similarly, the application of sensors-driven approaches are also transforming traditional SCs. Connected ecosystems resulting from the network of sensors facilitate the collections of information on production, transportation, weather, and operations of machines [91]. This equips the companies with the necessary information for planning, forecasting, monitoring, and visualization of the entire SCs. Ranging from RFID tags, Near Field Communication (NFC) to Bluetooth trackers, this digital approaches converts elements of physical environment to digital data that facilitate SC performance and reliability [92].

No matter the digital approach selected, it is crucial that the system should be cost-effective and efficient. Astill et al. highlight that the overhead costs associated with these tools must be minimized, and results in increased revenue as a result of transparency acquired in SCs [22]. Internet of Things (IoTs), for example, facilitate the development of large-scale smart infrastructure in SCs that merge the massive data, information, and all the processes of SCs [73]. This, in turn, simplifies not only strategies and planning in a given industry, but also provides the opportunity for real-time decision-making processes [93].

The commonality among the emerging digital approaches listed above is the trend towards "datafication" that is increasingly leading to the translation of the physical world into data, which could then be used to support decision-making in a dynamic, problem-oriented, and tailor-made way by combining data from various SC actors. For example, digitalization could help in many places to reliably record and measure the performance of suppliers through the collection, structuring, processing, and utilization of large volumes of data on environmental, social, and governance aspects [19]. In fact, this wealth of data and information from various SC actors in different formats and structures [94] advocates for the use of different digital approaches and instruments in itself.

As a result of our argumentation, the following heuristic framework can be summarized in Figure 1, which is discussed in the following section:

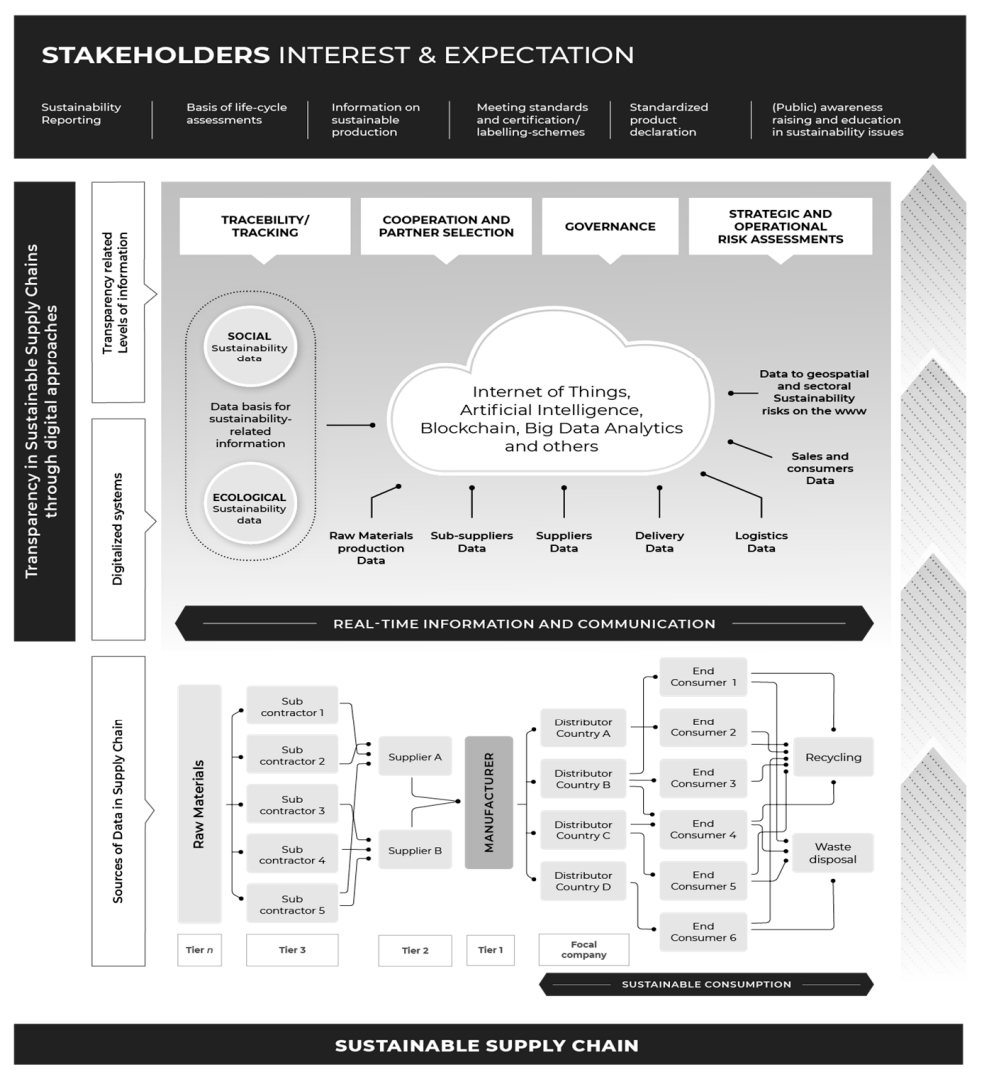

Figure 1. Heuristic framework incorporating digital approaches to dimensions of supply chain transparency (SCT). 


\subsection{Discussion of Incorporating Digital Approaches into Dimensions of SCT}

\subsubsection{Traceability/Tracking}

Tracing and tracking provide and verify product-related information and allocation of materials and activities across the SC to answer what/when/where questions. This is done by documentation and records identification [19]. The massive data and information exchanged only makes traceability and tracking efficient, but with digitalization approach as a mediator. In BT, all the transactions are recorded and encrypted with unique digital signatures, thus improving traceability and transparency. The validity and security of such data and information are attained by the use of cryptographic features of Blockchain [59]. Providers such as Accenture [95], IBM Vinturas [96], iPoint/better chain [97], or Minespider [98] offer Blockchain-supported traceability approaches, which enable "Mineral Supply Chain Due Diligence", for example. Since BT can be scaled to individual transactions and ensures that once verified data cannot be changed or manipulated, individual products can be transparently traced from their original materials to the end product, for example. Blockchain provides a shared, secure, and unalterable record of information flows for transactions. However, the data that is fed in must still be checked for plausibility and accuracy. Nevertheless, it is easy to trace who and when this data originated [99].

Another success story is the Swiss company Haelixa, which offers a different approach to traceability [42]. The product marking technology they have developed, which applies a traceable physical marker with specific information to raw materials, can be traced throughout the entire processing route, and can also be read out in the end product along with its information. In conjunction with digital technologies, a certifiable tracing/tracking and authentic system can be set up [80].

On the other hand, the end to end data collection and processing by the AI instruments, allows SCs stakeholders to get full system visibility in real-time, which facilitates the traceability across the complex SCs systems [100]. Likewise, a shared platform solution resulting from the use of cloud-computing provides an opportunity for information disclosure and sharing among stakeholders, thus enhancing visibility and transparency in the entire SC network. A web browser application facilitates the access of the information which is stored either on local in-house serves or public servers [88]. It is worth noting that as these digital approaches facilitate traceability and transparency across the SSCM, the big data act as the catalyst, as meaningful information is derived from the massive data for informed decision-making processes.

\subsubsection{Cooperation and Partner Selection}

The involvement of suppliers and sub-suppliers in SSCM comes with several new challenges. The activities of one sub-supplier can cause huge damage to other actors in the SCs. The case of Rana plaza is just one example where the reputation of involved companies was affected by the actions of a sub-contractor. In the selection of partners and suppliers, the incorporation of the benefits, opportunities, costs, and risks (BOCR) concept is constructed to evaluate various aspects of suppliers [101]. Different platform solutions have also been developed in the area of cooperation management to support supplier management, e.g., consensus-based trust among participants in BT facilitates collaboration, and thus flexible sharing and disclosure of information. Likewise, Cloud-computing platforms through web-based approaches to managing codes of conduct, self-assessments, evaluation and benchmarking, auditing, or monitoring and development [102]. With the ability to coordinate multi-agents' systems and operations, both AI-driven and Cloud-computing platforms enhance the integration [103] and interaction of multiple stakeholders involved in the SSCM. Fossas-Olalla et al. [104] conclude this kind of cooperation not only facilities higher levels of innovation, but also improves the financial performance of participating companies. For example, EcoVadis platform [105] and the Fair Factories Clearinghouse platform [106], which provides various tools specifically for the textile industry, e.g., for shared audits. Cloud-based databases, for example, are currently being tested to enable actor-oriented supply chain mapping. The Sustainabill approach [11], for example, helps to identify actors by making value-added 
networks transparent through the anonymous disclosure of supplier structures of the participating companies. The cloud platform visualizes the SC (multi-tier transparency) and supports traceability back to the origin.

The Scoutbee $\mathrm{GmbH}$ is pursuing a somewhat different approach [107]. It uses an AI-based software solution that draws on Big Data from various sources to help companies find suppliers and provide in-depth market information. Still, other approaches deal with the sharing of information such as audit results by promoting BT in initial pilot projects to reduce the risk of manipulation within the shared data [102].

\subsubsection{Control (Governance)}

Records access and keeping play a critical role in the governance of SCs. This facilitates, for instance, the controlling and management of sustainability-oriented SCs. Driven by the distributed and shared ledgers representing transactions, BT platforms facilitate SC governance as both formal and informal information is among the SC stakeholders [19]. For instance, both the private and public BT based platforms facilitate information that is accessible [85], which are useful in SCs governance and monitoring. Similarly, cloud computing provides an opportunity to implement guidelines, regulations, and code of conducts, which according to Garcia-Torres et al. [19], are legal mechanisms that bind companies in the identification, controlling or even preventing environmental and human rights violations resulting from their entire SCs [61]. These platforms also have prescribed indicators ranging from sustainability factors that act as management parameters for the various suppliers and sub-suppliers. This, in turn, facilitates the ranking of actors' performance regarding social and environmental sustainability, hence promoting the visibility of the entire SC. For instance, Sustainabill Cloud platform employs human rights issues and carbon emissions as part of their indicators of suppliers mapping, ranking, and management [11].

\subsubsection{Strategic and Operational Risk Assessments}

Internet-based platforms or cloud computing solutions have proven to be a strategic solution to information sharing, knowledge exchange, and integration. It plays a significant role in SCs, especially in the strategic and operational risk management. In Supply Chain Risk management (SCRM), three-level cyclical and interconnected processes are mostly considered [108]. These processes include risk identification, risk assessment, and risk mitigation. These processes call for a collaborative and coordinated initiative among the actors. Accordingly, platforms have emerged as a tool to enforce and facilitate this cooperation and coordination.

In this vein, data and information contributed by each stakeholder are used for the identification of sector-specific or cross-sectoral sustainability risks. Tools such as Cloud-computing, AI, and BT are used either as an individual tool or as a combination of two or more tool. For example, companies such as Sustainabill $\mathrm{GmbH}$ apply cloud platforms to identify SC networks and sustainability issues such as human rights violations and carbon emissions [11]. Similarly, CSR Risk Check, developed by MVO Nederland and supported by the Dutch Ministry of Foreign Affairs, can provide risk information for importing or foreign-producing companies that have been assessed based on more than 2750 data sources [109].

In light of the above, platform-oriented approach act as a catalyst to both cooperative- and compliance-based CSR paradigms. Third parties such as the government, NGOs, and other standards and certification bodies are used as a mechanism for monitoring and communicating the credentials of every part of the network to the stakeholders $[1,16]$. These parties act as a bridge to enhance some degree of certainty.

\section{Conclusion and Contribution}

This paper provides aspects that act as a conversation starter by exploring the existing digital approaches as instruments to facilitate SCT as an element to enhance SSCM. As the argumentation 
shows, there are various digital tools existing, addressing different levels and functional purposes, which are summarized in Table 1, below:

Table 1. Summary of digital approaches based on the heuristic framework on sustainability oriented transparency.

\begin{tabular}{|c|c|c|c|c|}
\hline $\begin{array}{c}\text { Digital } \\
\text { Approaches }\end{array}$ & Traceability and Tracking & $\begin{array}{l}\text { Cooperation and } \\
\text { Partners Selection }\end{array}$ & Governance & $\begin{array}{l}\text { Strategic and Operational } \\
\text { Risk Assessment }\end{array}$ \\
\hline $\begin{array}{l}\text { Blockchain } \\
\text { Technologies }\end{array}$ & $\begin{array}{l}\text { Transactional records with unique } \\
\text { and encrypted digital signatures } \\
\text { and unique identities for products } \\
\text { and partners facilitates tracing } \\
\text { and tracking of products to } \\
\text { individual suppliers and } \\
\text { sub-suppliers (the products' } \\
\text { country of origin, compliance } \\
\text { with sustainability certifications } \\
\text { and standards etc.). }\end{array}$ & $\begin{array}{l}\text { Consensus- based trust and } \\
\text { collaboration facilitates the } \\
\text { connection between } \\
\text { stakeholders in SCs. } \\
\text { Flexibility of information } \\
\text { access and sharing among } \\
\text { stakeholders bridges the gap } \\
\text { between them. }\end{array}$ & $\begin{array}{l}\text { Distributed and } \\
\text { shared ledgers } \\
\text { Limited and authorized } \\
\text { access to information among } \\
\text { the stakeholders } \\
\text { Multiple and synchronized } \\
\text { data thus facilitating } \\
\text { SC resilience. }\end{array}$ & $\begin{array}{l}\text { Tamper-roof and } \\
\text { incorruptible platforms with } \\
\text { multiple copies of ledgers } \\
\text { limits risk assessments to } \\
\text { only information sharing } \\
\text { and not the identification of } \\
\text { risks and hot spots. }\end{array}$ \\
\hline $\begin{array}{l}\text { Artificial } \\
\text { Intelligences and } \\
\text { Big Data Analytics }\end{array}$ & $\begin{array}{l}\text { Collection and processing of Big } \\
\text { Data to real-time information } \\
\text { facilitate Visibility of the entire SC }\end{array}$ & $\begin{array}{l}\text { Multi-agent systems } \\
\text { operations tools facilitate } \\
\text { interaction of stakeholders } \\
\text { in the SCs. } \\
\text { Conceptualization of } \\
\text { real-time information for } \\
\text { decision making processes }\end{array}$ & $\begin{array}{l}\text { End to end data collection } \\
\text { and processing. }\end{array}$ & $\begin{array}{l}\text { Predicable analytics for risk } \\
\text { identification, risk } \\
\text { assessment and } \\
\text { risk mitigation } \\
\text { Real-time information }\end{array}$ \\
\hline $\begin{array}{l}\text { Cloud Computing } \\
\text { Platforms }\end{array}$ & $\begin{array}{l}\text { Unique identities to verify } \\
\text { authentic goods and thus the } \\
\text { identification of the suppliers and } \\
\text { sub-suppliers involved. }\end{array}$ & $\begin{array}{l}\text { Multi-agent systems } \\
\text { operations tools used for SC } \\
\text { mapping and } \\
\text { information sharing. }\end{array}$ & $\begin{array}{l}\text { Resource and costs } \\
\text { optimizing platform } \\
\text { Graphic networks of the } \\
\text { entire Sustainable SC thus } \\
\text { necessary for the } \\
\text { management and ranking of } \\
\text { suppliers and sub-suppliers. }\end{array}$ & $\begin{array}{l}\text { Visibility of the entire SC. } \\
\text { Real-time identification of } \\
\text { the sustainability } \\
\text { related risks }\end{array}$ \\
\hline $\begin{array}{l}\text { IoTs-Sensors-driven } \\
\text { applications }\end{array}$ & $\begin{array}{l}\text { Connected ecosystems of sensors } \\
\text { facilitates massive collection and } \\
\text { processing sustainability-related } \\
\text { information and sharing SC } \\
\text { stakeholders for decision } \\
\text { making process }\end{array}$ & $\begin{array}{l}\text { Efficient and reliable } \\
\text { networking and } \\
\text { communication } \\
\text { Real-time and valuable } \\
\text { information resulting from } \\
\text { analytical features facilitates } \\
\text { stakeholders interactions } \\
\text { and collaboration. }\end{array}$ & $\begin{array}{l}\text { Production, transportation, } \\
\text { storage and delivery of } \\
\text { products and services } \\
\text { monitored and managed by } \\
\text { using real-time data and } \\
\text { real-time analytics, the parts } \\
\text { of the IoTs ecosystem can be } \\
\text { better networked }\end{array}$ & $\begin{array}{l}\text { Connected ecosystems of } \\
\text { sensors facilitates massive } \\
\text { collection and processing } \\
\text { data for predicting strategic } \\
\text { and operational risks. }\end{array}$ \\
\hline
\end{tabular}

However, as per this initial analysis, the market is developing dynamically, but is still driven more by individual initiatives. In many of these initiatives, the digital approaches used so far are still in the trial phase or offer only limited solutions. The analysed approaches, including BT, AI, Cloud computing, and sensors-driven applications to provide potential SSCT in SSCM. Based on this study, these approaches facilitate the development in traceability and tracking, collaboration and partner selections, governance, and strategic and operational risk assessment. Consequently, this article initiates a conversation among SSCM stakeholders and scholars on a collaborative approach towards the implementation of integrated digital approaches in SSCM.

As a starting point, the significance should also be placed in the identification of information dimensions using various perspectives, for instance, Berzau [66]'s risk-based information approach that focuses on the risks of violations of labour, social, and environmental standards in the SCs, or Garcia-Torres et al.'s perspective as discussed in [19]. The first results shows, that there is a trend of individualizing different digital approaches for the specific purposes in companies using internal data architecture and the existing technological environment. Therfore, there is a need for a discussion on the fit of technological solutions in order to standardize them for all partners in the supply chain.

Due to a lack of standardized information needs of different stakeholders aimed at transparency in the global value chain, it is difficult for companies to choose the appropriate digital approach for the specific transparency needs. In addition, a catch-all technology does not exist. Therfore, future research and innovation should identify the interfaces and also work on the integration of the different digital approaches.

As a conceptual article, the current study focuses on proposing new relationships among constructs of research and creating logical and complete arguments rather than testing them empirically [110]. This provides a ground for future research, which could explore the digital approaches as instruments 
to facilitate SSCT as an element to enhance SSCM through case studies and interviews with practitioners and researchers in this field.

Likewise, this study did not focus on the challenges of implementing digital approaches as SSCT instruments in SSCM. This is another limitation, and a research direction is possible in this focus. Furthermore, the study does not claim that these approaches work in the SCs of all industries. An investigation is needed to look at trade-offs that exist in the implementation of digital approaches, for instance, the question of data security and protection of intellectual property as well as the trade-off between privacy and transparency.

Author Contributions: This article was a joint work F.E. and B.O. within the regular framework of the Department of Sustainability-oriented Innovations and Transformation Management, Nuremberg Campus of Technology (NCT). All authors have read and agreed to the published version of the manuscript.

Funding: This research received no external funding.

Acknowledgments: We thank the members of Department of Sustainability-oriented Innovations and Transformation Management for their comments and support during the process of writing this article. Our sincere gratitude goes to the reveiwers for their valid comments which guided us in revising this article accordingly.

Conflicts of Interest: The authors declare no conflict of interest.

\section{References}

1. Yawar, S.A.; Seuring, S. Management of Social Issues in Supply Chains: A Literature Review Exploring Social Issues, Actions and Performance Outcomes. J. Bus. Ethics 2015, 141, 621-643. [CrossRef]

2. Campos, P.F.; Trucco, P.; Huatuco, L.H. Managing structural and dynamic complexity in supply chains: Insights from four case studies. Prod. Plan. Control. 2019, 30, 611-623. [CrossRef]

3. Schmeisser, B. A Systematic Review of Literature on Offshoring of Value Chain Activities. J. Int. Manag. 2013, 19, 390-406. [CrossRef]

4. Egels-Zandén, N.; Hulthen, K.; Wulff, G. Trade-offs in supply chain transparency: The case of Nudie Jeans Co. J. Clean. Prod. 2015, 107, 95-104. [CrossRef]

5. Khalid, R.U.; Seuring, S. Analyzing Base-of-the-Pyramid Research from a (Sustainable) Supply Chain Perspective. J. Bus. Ethics 2017, 155, 663-686. [CrossRef]

6. Heuer, M.A.; Khalid, U.; Seuring, S. Bottoms up: Delivering sustainable value in the base of the pyramid. Bus. Strat. Environ. 2020, 29, 1605-1616. [CrossRef]

7. Boström, M.; Jönsson, A.M.; Lockie, S.; Mol, A.P.; Oosterveer, P. Sustainable and responsible supply chain governance: Challenges and opportunities. J. Clean. Prod. 2015, 107, 1-7. [CrossRef]

8. Sauer, P.; Seuring, S. Extending the reach of multi-tier sustainable supply chain management-Insights from mineral supply chains. Int. J. Prod. Econ. 2019, 217, 31-43. [CrossRef]

9. Ebinger, F.; Goldbach, M.; Schneidewind, U. Greening supply chains: A competence-based perspective. In Greening the Supply Chain; Springer: London, UK, 2006; pp. 251-269.

10. Busse, C.; Schleper, M.C.; Niu, M.; Wagner, S.M. Supplier development for sustainability: Contextual barriers in global supply chains. Int. J. Phys. Distrib. Logist. Manag. 2016, 46, 442-468. [CrossRef]

11. Hofmann, H.; Busse, C.; Bode, C.; Henke, M. Sustainability-Related Supply Chain Risks: Conceptualization and Management. Bus. Strat. Environ. 2013, 23, 160-172. [CrossRef]

12. Sustainabill. Supply Chain Insights for Sustainable Business. 2020. Available online: https://www.sustainabill. de (accessed on 15 April 2020).

13. Sustainable Outdoor Clothing Gear: VAUDE. 2020. Available online: https://www.vaude.com/en-INT/ (accessed on 15 June 2020).

14. Bastian, J.; Zentes, J. Supply chain transparency as a key prerequisite for sustainable agri-food supply chain management. Int. Rev. Retail. Distrib. Consum. Res. 2013, 23, 553-570. [CrossRef]

15. Singh, A.; Mishra, N.; Ali, S.I.; Shukla, N.; Shankar, R. Cloud computing technology: Reducing carbon footprint in beef supply chain. Int. J. Prod. Econ. 2015, 164, 462-471. [CrossRef]

16. Hannibal, C.; Kauppi, K. Third party social sustainability assessment: Is it a multi-tier supply chain solution? Int. J. Prod. Econ. 2019, 217, 78-87. [CrossRef] 
17. Gold, S.; Heikkurinen, P.P. Transparency fallacy: Unintended consequences of stakeholder claims on responsibility in supply chains. Account. Audit. Account. J. 2018, 31, 318-337. [CrossRef]

18. Frentrup, M.; Theuvsen, L. Transparency in supply chains: Is trust a limiting factor? In Trust and Risk in Business Networks: Proceedings of the 99th Seminar of the European Association of Agricultural Economists (EAAE), Bonn, Germany, 8-10 February 2006; Univ. ILB: Bonn, Germany, 2009.

19. Garcia-Torres, S.; Albareda, L.; Rey-Garcia, M.; Seuring, S. Traceability for sustainability-Literature review and conceptual framework. Supply Chain Manag. Int. J. 2019, 24, 85-106. [CrossRef]

20. Espiñeira, M.; Santaclara, F.J. (Eds.) Advances in Food Traceability Techniques and Technologies: Improving Quality throughout the Food Chain; Woodhead Publishing: Amsterdam, Netherlands, 2016.

21. Behnke, K.; Janssen, M. Boundary conditions for traceability in food supply chains using blockchain technology. Int. J. Inf. Manag. 2020, 52, 101969. [CrossRef]

22. Astill, J.; Dara, R.A.; Campbell, M.; Farber, J.M.; Fraser, E.D.; Sharif, S.; Yada, R.Y. Transparency in food supply chains: A review of enabling technology solutions. Trends Food Sci. Technol. 2019, 91, 240-247. [CrossRef]

23. Ahmed, W.; Omar, M. Drivers of supply chain transparency and its effects on performance measures in the automotive industry: Case of a developing country. Int. J. Serv. Oper. Manag. 2019, 33, 159-186.

24. Mol, A.P. The Future of Transparency: Power, Pitfalls and Promises. Glob. Environ. Politics 2010, 10, $132-143$. [CrossRef]

25. Valentinov, V.; Verschraegen, G.; Van Assche, K. The limits of transparency: A systems theory view. Syst. Res. Behav. Sci. 2019, 36, 289-300. [CrossRef]

26. Krause, R. The Promotion of Labour Standards Through International Framework Agreements. In Labour Standards in International Economic Law; Springer: Cham, Switzerland, 2018; pp. 319-339.

27. Montecchi, M.; Plangger, K.; Etter, M. It's real, trust me! Establishing supply chain provenance using blockchain. Bus. Horiz. 2019, 62, 283-293. [CrossRef]

28. Hosseini, M.; Shahri, A.; Phalp, K.; Ali, R. Four reference models for transparency requirements in information systems. Requir. Eng. 2017, 23, 251-275. [CrossRef]

29. Grzybowska, K. Sustainable Logistics and Production in Industry 4.0: New Opportunities and Challenges; Springer Nature: Cham, Switzerland, 2020.

30. Müller, M.; Gaudig, S. An empirical investigation of antecedents to information exchange in supply chains. Int. J. Prod. Res. 2011, 49, 1531-1555. [CrossRef]

31. Adiputra, I.M.P.; Utama, S.; Rossieta, H. Transparency of local government in Indonesia. Asian J. Account. Res. 2018, 3, 123-138. [CrossRef]

32. Lotfi, Z.; Mukhtar, M.; Sahran, S.; Taeizadeh, A. Information Sharing in Supply Chain Management. Procedia Technol. 2013, 11, 298-304. [CrossRef]

33. Gurzawska, A. Towards Responsible and Sustainable Supply Chains-Innovation, Multi-stakeholder Approach and Governance. Philos. Manag. 2019, 1-29. [CrossRef]

34. Zhu, S.; Song, J.; Hazen, B.T.; Lee, K.; Cegielski, C. How supply chain analytics enables operational supply chain transparency. Int. J. Phys. Distrib. Logist. Manag. 2018, 48, 47-68. [CrossRef]

35. Kaitharath, T.J. New Paradigm of CSR for the Global Economy. J. Manag. Res. Anal. 2015, 2, $231-237$.

36. Agan, Y.; Kuzey, C.; Acar, M.F.; Açıkgöz, A. The relationships between corporate social responsibility, environmental supplier development, and firm performance. J. Clean. Prod. 2016, 112, 1872-1881. [CrossRef]

37. Lim, M.K.; Tseng, M.-L.; Tan, K.; Bui, T.D. Knowledge management in sustainable supply chain management: Improving performance through an interpretive structural modelling approach. J. Clean. Prod. 2017, 162, 806-816. [CrossRef]

38. Li, G.; Li, S.; Yang, X. Relationships among CSR, Innovation and Value Creation: An Empirical Study Based on China Listed Companies. ICLEM 2014, 2014, 1169-1174. [CrossRef]

39. Awaysheh, A.; Klassen, R.D. The impact of supply chain structure on the use of supplier socially responsible practices. Int. J. Oper. Prod. Manag. 2010, 30, 1246-1268. [CrossRef]

40. Pagell, M.; Wu, Z. Building a More Complete Theory of Sustainable Supply Chain Management Using Case Studies of 10 Exemplars. J. Supply Chain Manag. 2009, 45, 37-56. [CrossRef]

41. Seuring, S.; Müller, M. From a literature review to a conceptual framework for sustainable supply chain management. J. Clean. Prod. 2008, 16, 1699-1710. [CrossRef]

42. Haelixa. Unravelling Global Supply Chain Complexity. 2020. Available online: http://www.haelixa.com/ (accessed on 20 April 2020). 
43. Gött, H. (Ed.) Labour Standards in International Economic Law; Springer: Cham, Switzerland, 2018.

44. Khan, S.R. Apparel Sector: Ensuring Transparency in Global Supply Chain. Available online: https:/thefinancialexpress. com.bd/views/apparel-sector-ensuring-transparency-in-global-supply-chain-1557933407 (accessed on 14 June 2020).

45. Perks, K.J.; Viana, M.R.; Farache, F.; Kollat, J. A critical reflection on the role of dialogue in communicating ethical CSR through digital platforms. In Communicating Corporate Social Responsibility in the Digital Era; Routledge: Abingdon, Oxon, UK, 2017; pp. 133-143.

46. Pagell, M.; Shevchenko, A. Why Research in Sustainable Supply Chain Management Should Have no Future. J. Supply Chain Manag. 2014, 50, 44-55. [CrossRef]

47. Lund-Thomsen, P.; Oxborrow, L. Sustainable supply chain management. In Business Student's Guide to Sustainable Management, The Principles and Practice; Greenleaf Publishing: Sheffield, UK, 2015; pp. 218-238.

48. Zhang, D. A network economic model for supply chain versus supply chain competition. Omega 2006, 34, 283-295. [CrossRef]

49. Tan, K.C. A framework of supply chain management literature. Eur. J. Purch. Supply Manag. 2001, 7, 39-48. [CrossRef]

50. Gold, S.; Seuring, S.; Beske, P. Sustainable supply chain management and inter-organizational resources: A literature review. Corp. Soc. Responsib. Environ. Manag. 2009, 17, 230-245. [CrossRef]

51. Kwon, I.-W.G.; Suh, T. Factors Affecting the Level of Trust and Commitment in Supply Chain Relationships. J. Supply Chain Manag. 2004, 40, 4-14. [CrossRef]

52. Sahay, B. Understanding trust in supply chain relationships. Ind. Manag. Data Syst. 2003, 103, 553-563. [CrossRef]

53. Aschehoug, S.H.; Boks, C. Towards a framework for sustainability information in product development. Int. J. Sustain. Eng. 2013, 6, 94-108. [CrossRef]

54. Francisco, K.; Swanson, D. The Supply Chain Has No Clothes: Technology Adoption of Blockchain for Supply Chain Transparency. Logistics 2018, 2, 2. [CrossRef]

55. Brun, A.; Karaosman, H.; Barresi, T. Supply Chain Collaboration for Transparency. Sustainability 2020, 12, 4429. [CrossRef]

56. Alvarado Moore, K. Value Mapping Framework Involving Stakeholders for Supply Chain Improvement when Implementing Information Technology Projects. Ph.D. Thesis, University of Central Florida, Orlando, FL, USA, 2008.

57. Econsense-Forum Nachhaltige Entwicklung der Deutschen Wirtschaft e.V. Wert(e) Schaffen. Vier Hebel für Nachhaltigere Wertschöpfungsnetzwerke. Unter Mitarbeit von Laura Franken und Carolin Gürtürk. 2019. Available online: https://econsense.de/app/uploads/2019/11/econsense-Diskussionsbeitrag-2019-Werteschaffen.pdf (accessed on 15 April 2020).

58. Bell, S.; Berg, T.; Morse, S. Rich Pictures: Sustainable Development and Stakeholders - The Benefits of Content Analysis. Sustain. Dev. 2015, 24, 136-148. [CrossRef]

59. Moser, R.; Schaefers, T.; Meise, J.N. Consumer Preferences for Product Transparency in Emerging Markets-Lessons Learned from India. Mark. Rev. St. Gallen 2012, 29, 22-27. [CrossRef]

60. Hofstede, G.J. Transparency in Netchains. Information Technology for a Better Agri-Food Sector, Environment and Rural Living; Debrecen University: Debrecen, Hungary, 2003; pp. 17-29.

61. Dickson, M.; Warren, H. A Look at Labor Issues in the Manufacturing of Fashion through the Perspective of Human Trafficking and Modern-day Slavery. Dangers Fash. 2020, 103. [CrossRef]

62. Hsu, C.-W.; Lee, W.-H.; Chao, W.-C. Materiality analysis model in sustainability reporting: A case study at Lite-On Technology Corporation. J. Clean. Prod. 2013, 57, 142-151. [CrossRef]

63. Ivanov, D.; Dolgui, A.; Sokolov, B.; Ivanova, M. Literature review on disruption recovery in the supply chain. Int. J. Prod. Res. 2017, 55, 6158-6174. [CrossRef]

64. Fritz, M.; Schiefer, G. The Challenge of Reaching Transparency: 'T-readiness' of Enterprises and Sector Networks. Int. J. Food Syst. Dyn. 2010, 3, 182-183.

65. Ebinger, F.; Omondi, B. Transparenz und Digitalisierung in Nachhaltigen Wertschöpfungsketten: Ansätze für ein Erfolgreiches CSR-Management, 4th ed.; Hildebrandt, A., Ed.; CSR und Digitalisierung: Berlin/Heidelberg, Germany, 2020.

66. Berzau, L. Prozessschritte Nachhaltiges Lieferkettenmanagement. Praxisorientierter Leitfaden für Unternehmen; Econsense-Forum Nachhaltige Entwicklung der Deutschen Wirtschaft e. V.: Berlin, Germany, 2017.

67. Gupta, A. Transparency Under Scrutiny: Information Disclosure in Global Environmental Governance. Glob. Environ. Politics 2008, 8, 1-7. [CrossRef] 
68. Duman, G.M. Big Data Analytics in Supply Chain Management: A Literature Review on Supply Chain Analytics. Eng. Posters 2017. Available online: https://core.ac.uk/reader/80106956 (accessed on 10 March 2020).

69. Menon, S.; Shah, S. An overview of digitalisation in conventional supply chain management. In MATEC Web of Conferences; EDP Sciences: Les Ulis, France, 2019; Volume 292, p. 01013.

70. Alkahtani, M.; Abidi, M.H. Supply Chain 4.0: A Shift in Paradigm. In Proceedings of the International Conference on Industrial Engineering and Operations Management, Pilsen, Czech Republic, 23-26 July 2019; IEOM Society International: Southfield, MI, USA, 2019; pp. 1698-1705.

71. Sivarajah, U.; Kamal, M.; Irani, Z.; Weerakkody, V. Critical analysis of Big Data challenges and analytical methods. J. Bus. Res. 2017, 70, 263-286. [CrossRef]

72. Dubey, R.; Gunasekaran, A.; Childe, S.J.; Papadopoulos, T.; Wamba, S.F. World class sustainable supply chain management: Critical review and further research directions. Int. J. Logist. Manag. 2017, 28, 332-362. [CrossRef]

73. Abdel-Basset, M.; Manogaran, G.; Mohamed, M.; Gunasekaran, M. Internet of Things (IoT) and its impact on supply chain: A framework for building smart, secure and efficient systems. Future Gener. Comput. Syst. 2018, 86, 614-628. [CrossRef]

74. Tsai, K. Where Graph Technology and Supply Chain Transparency Meet Corporate Social Responsibility. Available online: https://neo4j.com/case-studies/transparency-one/ (accessed on 26 May 2020).

75. Mehta, S. Socially Responsible Supply Chain Management: An Essence of Value Creation. J. Supply Chain Manag. Syst. 2016, 5, 28. [CrossRef]

76. Basta, M.; Lapalme, J.; Paquet, M.; Saint-Louis, P.; Abu Zwaida, T. How are supply chains addressing their social responsibility dilemmas? Review of the last decade and a half. Corp. Soc. Responsib. Environ. Manag. 2018, 25, 833-843. [CrossRef]

77. Min, H. Artificial intelligence in supply chain management: Theory and applications. Int. J. Logist. Res. Appl. 2009, 13, 13-39. [CrossRef]

78. Ardron, J.A.; Ruhl, H.A.; Jones, D.O.B. Incorporating transparency into the governance of deep-seabed mining in the Area beyond national jurisdiction. Mar. Policy 2018, 89, 58-66. [CrossRef]

79. Wu, Y.; Cegielski, C.G.; Hazen, B.T.; Hall, D.J. Cloud Computing in Support of Supply Chain Information System Infrastructure: Understanding When to go to the Cloud. J. Supply Chain Manag. 2013, 49, 25-41. [CrossRef]

80. Choi, T.-M. Blockchain-technology-supported platforms for diamond authentication and certification in luxury supply chains. Transp. Res. Part. E: Logist. Transp. Rev. 2019, 128, 17-29. [CrossRef]

81. Chod, J.; Trichakis, N.; Tsoukalas, G.; Aspegren, H.; Weber, M. On the Financing Benefits of Supply Chain Transparency and Blockchain Adoption. Manag. Sci. 2020. [CrossRef]

82. Saini, V. Blockchain in Supply Chain: Journey from Disruptive to Sustainable. J. Mech. Contin. Math. Sci. 2019, 14, 498-508. [CrossRef]

83. Pradhan, A.; Stevens, A.; Johnson, J. Blockchain Fundamentals for Supply Chain: A Guide to the New Boardroom Buzzword. Available online: https://www.gartner.com/en/doc/344447-blockchain-fundamentalsfor-supply-chain-a-guide-to-the-new-boardroom-buzzword (accessed on 15 June 2020).

84. Salah, K.; Nizamuddin, N.; Jayaraman, R.; Omar, M. Blockchain-Based Soybean Traceability in Agricultural Supply Chain. IEEE Access 2019, 7, 73295-73305. [CrossRef]

85. Pilkington, M. Blockchain technology: Principles and applications. In Research Handbook on Digital Transformations; Edward Elgar Publishing: Cheltenham, UK, 2016.

86. Thomassey, S.; Zeng, X. Introduction: Artificial Intelligence for Fashion Industry in the Big Data Era. In Artificial Intelligence for Fashion Industry in the Big Data Era; Springer: Singapore, 2018; pp. 1-6.

87. Baryannis, G.; Dani, S.; Validi, S.; Antoniou, G. Decision Support Systems and Artificial Intelligence in Supply Chain Risk Management. In Revisiting Supply Chain Risk; Springer: Cham, Switzerland, 2019; pp. 53-71.

88. Toka, A.; Aivazidou, E.; Antoniou, A.; Arvanitopoulos-Darginis, K. Cloud computing in supply chain management: An overview. In E-logistics and E-Supply Chain Management: Applications for Evolving Business; IGI Global: Hershey, PA, USA, 2013; pp. 218-231.

89. Lindner, M.; Robinson, P.; McLarnon, B.; McDonald, F. The cloud supply chain: A framework for information, monitoring, accounting and billing. In Proceedings of the 2nd International ICST Conference on Cloud Computing (CloudComp 2010), Barcelona, Spain, 25-28 October 2010.

90. Carroll, A.B. The pyramid of corporate social responsibility: Toward the moral management of organizational stakeholders. Bus. Horiz. 1991, 34, 39-48. [CrossRef] 
91. Ghanchi, J. Principal Ways IoT Can Benefit Supply Chain Management. Available online: https://theiotmagazine. com/principal-ways-iot-can-benefit-supply-chain-management-1be9981b1f1f (accessed on 10 July 2020).

92. Fitzgerald, J.; Mussomeli, A.; Daecher, A.; Chandramouli, M. Smart Sensors and Supply Chain Innovation: Deloitte US. Available online: https://www2.deloitte.com/us/en/pages/operations/articles/smart-sensors-andsupply-chain.html (accessed on 21 July 2020).

93. Abdullayeva, A. Impact of Artificial Intelligence on Agricultural, Healthcare and Logistics Industries. Ann. Spiru Haret Univ. Econ. Ser. 2019, 19, 167-175. [CrossRef]

94. BMUB (Bundesministerium für Umwelt, Naturschutz, Bau und Reaktorsicherheit); UBA (Umweltbundesamt). Schritt für Schritt zum nachhaltigen Lieferkettenmanagement_Praxisleitfaden für Unternehmen; BMUB: Berlin/Dessau, Germany, 2017.

95. Accenture. Blockchain. 2020. Available online: https://www.accenture.com/de-de/insights/blockchain-index (accessed on 15 April 2020).

96. IBM Vinturas. Redefining the Automobile Customer Journey with IBM Blockchain. 2020. Available online: https://www.ibm.com/case-studies/vinturas-ibm-blockchain (accessed on 15 April 2020).

97. iPoint. iPoint SustainHub. Die Universelle Plattform für Compliance \& Nachhaltigkeit. 2020. Available online: https://www.ipoint-systems.com/de/loesungen/sustainhub/ (accessed on 15 April 2020).

98. Minespider. Sustainable \& Responsible Supply Chain Tracking. 2020. Available online: https://www. minespider.com (accessed on 15 April 2020).

99. Pournader, M.; Shi, Y.; Seuring, S.; Koh, S.L. Blockchain applications in supply chains, transport and logistics: A systematic review of the literature. Int. J. Prod. Res. 2019, 58, 2063-2081. [CrossRef]

100. McKendrick, J. Artificial Intelligence Works Its Way into Supply Chains. Available online: https://www. zdnet.com/article/artificial-intelligence-works-its-way-into-supply-chains/ (accessed on 9 July 2020).

101. Lee, A.H.I. A fuzzy supplier selection model with the consideration of benefits, opportunities, costs and risks. Expert Syst. Appl. 2009, 36, 2879-2893. [CrossRef]

102. Econsense—Forum Nachhaltige Entwicklung der Deutschen Wirtschaft e. V. Ansätze für Lieferantenabfrage und -Management. Exemplarische Darstellung Webbasierter Lösungen. 2014. Available online: https:/econsense.de/app/ uploads/2018/06/econsense-Diskussionsbeitrag_Ans\%C3\%A4tze-f\%C3\%BCr-Lieferantenabfrage_2014.pdf (accessed on 15 April 2020).

103. Gandon, F. Distributed Artificial Intelligence and Knowledge Management: Ontologies and multi-Agent Systems for A Corporate Semantic Web. Ph.D. Dissertation, University of Nice Sophia Antipolis, Nice, France, 2002. Available online: https://tel.archives-ouvertes.fr/tel-00378201/document (accessed on 15 April 2020).

104. Fossas-Olalla, M.; Lopez-Sanchez, J.I.; Minguela-Rata, B. Cooperation with suppliers as a source of innovation. Afr. J. Bus. Manag. 2010, 4, 3491-3499.

105. EcoVadis. Die Weltweit Vertrauenswürdigsten Nachhaltigkeitsratings für Unternehmen. 2020. Available online: https://ecovadis.com/de/ (accessed on 15 April 2020).

106. Fair Factories Clearinghouse. Compliance Solutions for A Better World. 2020. Available online: https: //www.fairfactories.org/ (accessed on 15 April 2020).

107. Scoutbee. Smarte Lieferantensuche. 2020. Available online: https://scoutbee.com/de/ (accessed on 15 April 2020).

108. Tran, T.H.; Dobrovnik, M.; Kummer, S. Supply chain risk assessment: A content analysis-based literature review. Int. J. Logist. Syst. Manag. 2018, 31, 562-591. [CrossRef]

109. MVO Risk Check. CSR Risiko Check. 2020. Available online: https://www.mvorisicochecker.nl/de (accessed on 15 April 2020).

110. Gilson, L.L.; Goldberg, C.B. Editors' comment: So, what is a conceptual paper? Group Organ. Manag. 2015, 40, 127-130. [CrossRef]

(C) 2020 by the authors. Licensee MDPI, Basel, Switzerland. This article is an open access article distributed under the terms and conditions of the Creative Commons Attribution (CC BY) license (http://creativecommons.org/licenses/by/4.0/). 